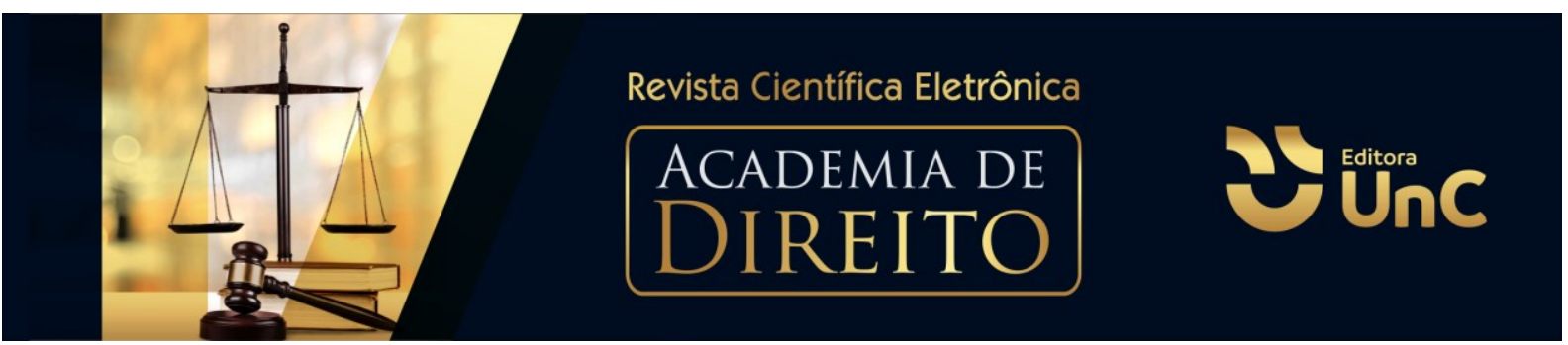

\title{
ILEGITIMIDADE DA COMISSÃO PROCESSANTE DISCIPLINAR FRENTE ÀS GARANTIAS CONSTITUCIONAIS DA AMPLA DEFESA E DO CONTRADITÓRIO
}

\section{ILLEGITIMITY OF THE DISCIPLINARY PROCEDURAL COMMITTEE AGAINST THE CONSTITUTIONAL WARRANTIES OF LARGE DEFENSE AND THE CONTRADICTORY}

\author{
Éverton Négri da Silva ${ }^{1}$ \\ Thiago Antônio Nascimento Monteiro Diniz ${ }^{2}$
}

\begin{abstract}
RESUMO
O presente trabalho teve como objetivo constatar e avaliar mediante pesquisa bibliográfica os preceitos do Processo Administrativo Disciplinar brasileiro, em que se observou quais parâmetros devem ser seguidos para a garantia dos direitos do indiciado e da devida legitimidade da Comissão Processante, mediante o método de raciocínio lógico-dedutivo, baseando-se na construção doutrinária e normativa. Buscando-se a resolução do seguinte questionamento: A inobservância dos princípios da ampla defesa e do contraditório implica na ilegitimidade dos atos da Comissão Processante em um processo administrativo disciplinar? Conclui-se que a legitimidade da Comissão não depende tão somente da observância das regras estabelecidas em lei, mas também com a interpretação e aplicação da norma com base nos princípios constitucionais, assim como a compreensão da matéria tanto pelos administradores quanto pelos indiciados, para que a ampla defesa e o contraditório sejam garantidos.
\end{abstract}

Palavras-Chave: Processo Administrativo. PAD. Garantias Constitucionais.

\begin{abstract}
The present research was objective to verify and evaluate through bibliographic research the precepts of the brazilian Disciplinary Administrative Process, which observed which parameters should be followed for the guarantee of the rights of the accused and the due legitimacy of the Processing Commission, through the method of logical-deductive reasoning, based on the doctrinal and normative construction.

\footnotetext{
${ }^{1}$ Acadêmico do curso de Direito da Universidade do Contestado (UnC). Santa Catarina. Brasil. E-mail: negri.ens@gmail.com

${ }^{2}$ Mestre em direitos fundamentais e democracia. Professor da Universidade do Contestado (UnC). Santa Catarina. Brasil. E-mail: thgdnz@gmail.com.
} 
Searching the resolution of the following question: Does failure to observe the principles of broad defense and contradictory imply the illegitimacy of the acts of the Processing Commission in a disciplinary administrative process? It is concluded that the legitimacy of the Commission depends not only on the observance of the precepts established by law, but also on the interpretation and application of the norm on the basis of constitutional principles, as well as the understanding of the matter by both administrators and those indicted for broad defense and the contradictory are guaranteed.

Keywords: Administrative Process. PAD. Constitutional Guarantees.

\section{INTRODUÇÃO}

A vedação da vingança privada e da autotutela dos particulares, historicamente, veio do Privilégio Exclusivo do Estado na busca pela justiça. Esse privilégio, ou poder estatal, está baseado na pretensão punitiva do Estado, e apresenta duas vertentes básicas sobre os indivíduos: o administrativo e o penal (ESPINOSA; SOARES, 2013, p. 03).

O poder estatal em punir será materializado mediante o processo, que agirá sobre aqueles que cometem algum ato ilícito, tanto de natureza penal, quanto administrativa (MELLO, 2010, p. 443-444).

Para as faltas cometidas administrativamente, há instrumentos que são utilizados para o esclarecimento dos fatos, pela busca da verdade, e não devem ser entendidos como uma ferramenta para castigar (SILVA; MELLO, 2018).

Esses instrumentos fazem parte do Processo Administrativo Disciplinar - em seu sentido amplo -. As teorias são de que há duas modalidades básicas no processo administrativo: a sindicância e o processo administrativo disciplinar em sentido estrito (PAD) (COSTA; BIANCHINI; GOMES, 2012, p. 133).

O entendimento do processo administrativo se faz necessário para cessar algumas práticas autoritárias e ultrapassadas que ainda existem em algumas repartições públicas. Pois, antes da Lei $\mathrm{n}^{\circ}$. 9.789/99 que trata do processo administrativo (LPA), era comum indeferimentos de recursos e outros atos sem a devida motivação. Mesmo após a LPA, há ainda desrespeito às garantias constitucionais no processo administrativo. Condutas essas que prejudicam a própria Administração (NOHARA; MARRARA, 2009, p. 02). 
Não obstante, questões morais/pessoais entre a autoridade administrativa, ou dos membros da comissão e o acusado podem estar envolvidas, coibindo dessa maneira o devido processo legal (ROSSETTO, 2010, p. 06).

Atitudes essas que comprometem a Legitimidade dos atos da Administração, pois não são condizentes com as normas, assim como cita Habermas (1997, p. 193) em sua pesquisa: a legitimidade tem sua presunção na legalidade.

Por conseguinte, são abordadas as características do Processo Administrativo Disciplinar, principais funções e limitações da comissão processante e, posteriormente, a abordagem da observância da ampla defesa e do contraditório, juntamente com os princípios que cercam o devido processo legal, justificando o entendimento dos preceitos que conferem a legitimidade à Comissão Processante.

Embasando, assim, o objetivo em constatar e avaliar mediante pesquisa bibliográfica os preceitos do Processo Administrativo Disciplinar brasileiro, em que se observou quais parâmetros devem ser seguidos para a garantia dos direitos do indiciado e da devida legitimidade da Comissão Processante, mediante o método de raciocínio lógico-dedutivo, baseando-se na construção doutrinária e normativa. Buscando-se a resolução do seguinte questionamento: A inobservância dos princípios da ampla defesa e do contraditório implica na ilegitimidade dos atos da Comissão Processante em um processo administrativo disciplinar?

Diante do exposto, percebe-se que o conhecimento das peculiaridades do processo administrativo disciplinar tanto pelos administradores, quanto dos administrados se faz necessário para trazer a legitimidade da Comissão ao processo, mantendo a boa imagem da Administração e garantindo, principalmente, os direitos do sindicado.

\section{DO PROCESSO ADMINISTRATIVO DISCIPLINAR}

O poder disciplinar é uma ferramenta que o Estado se utiliza para aplicar sanções ao seu quadro funcional, em razão de uma infração disciplinar (DIAS; BIANCHINI; GOMES, 2012, p. 137), cometida pelos seus agentes ou terceiros sujeitos à norma dos órgãos, fundada no princípio da hierarquia (ESPINOSA; SOARES, 2013, p. 05). 
Essa infração disciplinar será inquirida mediante um processo administrativo, conduzido por uma Comissão do Processo Administrativo Disciplinar, a qual terá como presidente da comissão um superior hierárquico ao investigado, designado pela autoridade competente, conforme artigo 149 da Lei $n^{\circ}: 8.112 / 90$.

Portanto, o objetivo do processo administrativo é auxiliar na busca pelo interesse público, exercendo funções como: controle da administração, inibir condutas arbitrárias pelos agentes, reduzir custos da máquina pública, garantir a segurança jurídica e documentação dos atos estatais (CAMPOS, 2019, p. 685).

O Estado, baseando-se no interesse público, na busca pela verdade, assume um lugar de superioridade em relação aos particulares. Essa preponderância vem através do princípio da "supremacia do interesse público sobre o privado", e é concomitante ao princípio da "indisponibilidade do interesse público". Esses dois princípios são a base do Direito Administrativo (ALMEIDA, 2019, pp. 46, 51).

A Administração Pública, então, na sua colocação executiva, dará cumprimento à vontade do Estado por meio de atos jurídicos, que são designados como atos administrativos. Desse modo, genericamente, há três categorias de atos: atos legislativos, atos judiciais e atos administrativos (MEIRELLES; BURLE FILHO; BURLE, 2016, p. 172-173).

Portanto, o ato administrativo é qualquer atividade ou ato propriamente dito da Administração Pública, sendo uma declaração unilateral do Estado, uma declaração jurídica e, assim, produzindo efeitos jurídicos. Os atos administrativos são derivados do próprio Estado ou daquele que esteja investido com direitos estatais (ZYMLER, 2005, p. 95).

O objetivo de um ato administrativo, através do interesse público, é adquirir, resguardar, transferir, modificar, declarar ou extinguir direitos ou impor deveres a própria administração ou a terceiros (COUTO, 2019, p. 362).

Ora, o processo administrativo é um ato administrativo. Será a exteriorização da vontade do administrador e, antes de virar um ato administrativo propriamente dito, deverá observar alguns procedimentos, dos quais deve ser motivado e, consequentemente, sindicado (ARAGÃO, 2013, p. 1.192).

Para o processo administrativo obter êxito, ele será exteriorizado pelo procedimento, que é uma continuidade de atos lógicos, para atingir um único objetivo. Logo, o processo administrativo é uma espécie do gênero processual e 
requer observância aos princípios gerais, que norteiam o processo: princípio da legalidade, da finalidade, da motivação, da razoabilidade, da proporcionalidade, da moralidade, da ampla defesa, do contraditório, da segurança jurídica, do interesse público, da eficiência, da celeridade, da economia, da publicidade, do impulso e da modicidade (MOREIRA NETO, 2014, p. 251).

A Lei Federal n. ${ }^{\circ}$ 9.784/99, que regula o processo administrativo no âmbito da Administração Pública Federal, em seu artigo $2^{\circ}$, através de seu parágrafo único e incisos seguintes, deixa claro ao estabelecer que o processo administrativo deve ser interpretado pela Administração Pública de forma a considerar os Princípios Gerais, conjugando com o Direito, ou seja, com o conjunto das normas que tenham relação com o caso em concreto.

Essa Lei, além de regular o processo administrativo na esfera federal, também é aplicável subsidiariamente no âmbito dos estados e municípios (ARAGÃO, 2013, p. 1.194; CAMPOS, 2019, p. 684).

É aplicada de modo complementar por força do artigo 22, da CF/88, referindose como competência exclusiva da União a criação de leis referentes à matéria processual, em seu inciso primeiro.

Lembrando que processo não se confunde com procedimento. Processo é um ordenamento de atos legais que possuem como objetivo alcançar um resultado conclusivo, podendo ser realizado por mais de um modo. Ao passo que o procedimento é o jeito específico da ordenação desses atos, é a formalização processual (ROCHA, 1997, p. 190).

Aragão (2013, p. 1.214-1.215) admite que, caso os estados não possuam legislação específica que trate de assuntos procedimentais, a Lei Federal n. 9.784 de 1.999 se aplica de forma subsidiária, com a finalidade da garantia da segurança jurídica dos administrados, ainda que é competência exclusiva da União para legislar sobre direito processual. Pode-se afirmar, então, que quando se tratar de questões processuais, a lei supracitada se aplicará a todos os estados e municípios, ao passo de que quando for matéria de procedimentos, serão observados apenas as que tiverem caráter geral.

Ainda que, nessa lei, há diversas normas explícitas que são consideradas "princípios do processo administrativo", que devem ser observadas, obviamente, na 
esfera federal e, ainda, em qualquer outro processo; de forma extensiva (ARAGÃO, 2013, p. 1.215; MEIRELLES; BURLE FILHO; BURLE, 2016, p. 821).

Pois, por mais que haja princípios oriundos da Constituição Federal, é interessante a promulgação de uma lei para dar solidez, materialidade, a esses princípios (NOHARA; MARRARA, 2009, p. 04).

$E$, ainda que a LPA implique unicamente no processo administrativo federal, deve ser acatada pelos estados e municípios por reforçar a garantia de princípios constitucionais (BACELLAR FILHO, 2013, p. 80).

Portanto, a lei não necessita abranger todas as ações previsíveis da Administração Pública, o quê não significa que a Administração é livre para agir dentro daquilo que a lei não proíba. Poderá, assim, fazer apenas atos com embasamento nas leis, "à luz da legalidade ampla/juridicidade", observando, sempre, os princípios previstos pela Constituição (ARAGÃO, 2013, p. 158).

Assim sendo, aquele que irá interpretar a lei e aplicá-la no processo administrativo, deverá sempre se basear na supremacia do Estado sem, entretanto, deixar de observar as garantiras do particular. Deverá haver equilíbrio entre os privilégios do Estado e os direitos individuais (ALMEIDA, 2019, p. 48-49).

Deverá garantir os direitos fundamentais pelo fato da grande relevância do ato na vida dos indivíduos por criar, modificar ou extinguir direitos ou obrigações (ARAGÃO, 2013, p. 308-309).

Os atos administrativos possuem grande importância ainda mais porque não há igualdade entre o Estado e o particular. Entre os particulares há igualdade entre as partes em uma relação jurídica. Já no Direito Público, há a supremacia do Poder Público sobre os indivíduos. A partir dessa desigualdade, que é originária da prevalência dos interesses coletivos sobre os individuais, derivam-se notórios privilégios e prerrogativas para a Administração Pública (MEIRELLES; BURLE FILHO; BURLE, 2016, p. 52).

Desse modo, o administrador público é obrigado, em todo o seu labor, a observar os preceitos legais e às necessidades do "bem comum". Caso ele cometa desvios ou se afaste da legalidade poderá sofrer responsabilidades administrativas (disciplinares), cíveis ou criminais, conforme o caso; ainda, será considerada a sua ação um Ato Administrativo inválido (MEIRELLES; BURLE FILHO; BURLE, 2016, p. 93). 
Em resumo, toda atuação da Administração deve ser pautada no interesse público, é esse seu motivo, o impulso e o primórdio de toda conduta. Então quando um agente comete alguma falta administrativa, o "inquérito" realizado sobre esse fato nada mais é que o interesse público implícito pela manutenção da moralidade e da legalidade do serviço público, tanto pela apuração da infração, quanto imposto àquele que irá investigar o fato.

Em todo caso deverá haver uma formalidade para materializar esse processo, que será através dos procedimentos representados pelos atos administrativos, sendo o objetivo a apuração do caso e não necessariamente a imposição de uma sansão ao administrado.

Mas, uma vez aplicada a penalidade ao funcionário, essa poderá ser revisada, pois o julgamento do processo administrativo não faz coisa julgada (ZYMLER, 2005, p. 101). Porém, o Judiciário poderá rever apenas o quê diz respeito à legalidade do ato e a sua legitimidade. Não poderá avaliar o Mérito Administrativo, que é a oportunidade e a conveniência do administrador perante o fato em concreto, ou seja, sua discricionariedade legal (CARVALHO FILHO, 2019, p. 129-130).

$O$ requisito necessário para se iniciar um Processo Administrativo Disciplinar é a certeza de um ato ilícito administrativo e a sua autoria. Caso contrário, o Processo Administrativo Disciplinar em sentido estrito deve ser sempre precedido de uma Sindicância, assim quando a conduta do servidor deixar dúvidas sobre sua ilicitude, ou quando não houver certeza dos fatos (ESPINOSA; SOARES, 2013, p. 14).

Pois, das infrações cometidas pelo funcionário público que forem apenadas somente com advertência ou suspensão por até trinta dias, a sindicância será o meio sumário de apuração desses atos ilícitos (SPITZCOVSKY, 2019, p. 596).

Conforme a doutrina majoritária, a Sindicância é um procedimento "informal", mais rápido e simples, com objetivo de apurar o quê aconteceu, para conhecer se houve ou não irregularidades por partes dos agentes públicos (DI PIETRO, 2018, p. 807).

Quando dessa Sindicância houver aplicação de penalidades, ela deverá seguir os mesmos critérios do PAD, apesar de mais rápida, deverá garantir a ampla defesa (KNOPLOCK, 2018, p. 325). 
Do mesmo feito, o Processo Administrativo Disciplinar - em sentido estrito (PAD), é um procedimento mais trabalhoso e formal e, por isso, possui prazos maiores do que ao comparado com a Sindicância. Por esse motivo, essa ferramenta processual é para a verificação de infrações graves, que podem resultar na exclusão do agente do setor público (CAMPOS, 2019, p. 494-495).

Lembrando que, conforme a súmula vinculante n. ${ }^{\circ} 05$ do STF (BRASIL, 2008), não há previsão legal da obrigatoriedade de que o indiciado faça-se presente com um advogado no PAD, o quê não ofenderá a Constituição de 1988.

O PAD deverá então ser sindicado por outros funcionários públicos distintos daquele (s) envolvido (s) no fato a ser apurado, os quais irão compor uma Comissão Processante, ou Sindicante. É a Comissão que realizará o apuramento da possível infração administrativa e deverá observar os direitos constitucionais do sindicado

\section{DA COMISSÃO PROCESSANTE}

Como demonstrado anteriormente, o superior hierárquico conhecendo uma atitude que configure uma infração funcional pelo seu inferior, não tem o poder para que imponha uma sanção a esse, não de modo legítimo. Há então, a necessidade de um procedimento para apurar a tal conduta do subordinado, de modo que essa prática esteja prevista em lei, ou seja, conforme o processo administrativo disciplinar (ESPINOSA; SOARES, 2013).

Esse procedimento visará à inquisição da infração disciplinar mediante um processo administrativo, que será conduzido por uma Comissão do Processo Administrativo Disciplinar. Essa comissão deverá ser integrada por um presidente e mais dois servidores estáveis, sendo o presidente da comissão um superior hierárquico ao investigado, designado pela autoridade competente (BRASIL, 1991; COSTA; BIANCHINI; GOMES, 2012, p. 135).

A instauração do processo administrativo disciplinar que definirá a Comissão. Nada mais é que um ato formal da autoridade competente, através de uma portaria. Nela deverão constar os nomes e as matrículas dos integrantes, com seus respectivos cargos, já definindo o tipo do procedimento que será adotado (sindicância ou PAD), além da estipulação do prazo para a Comissão concluir o trabalho (MARINELA, 2018, p. 1.159). 
Entende-se por autoridade competente aquela que tem a função legal para gerir os servidores públicos e, consequentemente, aquela que irá exercer o poderdever disciplinar. A exceção é quando a autoridade competente for aquela que é dirigente de entidades da Administração Pública, que não está vinculada sob a hierarquia do funcionário infrator, mas possui poder-dever disciplinar de supervisão ministerial. Se o funcionário que presenciar a falta administrativa não for a autoridade competente, deverá esse informar o fato a quem o for (ARAGÃO, 2013, p. 1.036).

A autoridade disciplinar, então, instala o processo administrativo; designa uma comissão processante e, após o término dos procedimentos, julga o ato. Ora, a competência disciplinar é partilhada entre a autoridade disciplinar e a Comissão Processante (ARAGÃO, 2013, p. 1.036).

Desse modo, o processo administrativo seguirá cinco fases comuns, com o objetivo de criar uma decisão perante o órgão competente, nesta ordem: instauração, instrução, defesa, relatório e o julgamento - ou decisão (DI PIETRO, 2018, p. 806).

Porém, não basta, tão somente, a legalidade na compreensão das normas, há de se utilizar também os princípios constitucionais, que devem ser entendidos como "bússolas", a guiar as atitudes e decisões do administrador público. Com isso, acredita-se em uma verdadeira compreensão e futura aplicação das leis infraconstitucionais (ROSSETTO, 2010, p. 05).

Nesse cenário, a instauração dá-se no momento em que a autoridade competente constata ou tem ciência da possível infração administrativa e promove a sua imediata apuração, mediante sindicância ou inquérito administrativo (BRASIL, 1990, art. 143).

Então, a autoridade administrativa, incumbida da função administrativa e, no exercício dela, deverá fazer o estudo da infração para ser imputada de forma válida ao agente que a praticou, observando os princípios básicos, quais sejam: legalidade; anterioridade; tipicidade e voluntariedade; para depois serem avaliadas as sanções, se houver, aos princípios: proporcionalidade; devido processo legal e motivação (MELLO, 2010, p. 849-850).

Essa é a contemporânea disposição da "jurisdicionalização do poder disciplinar", que inflige à Administração Pública ações formais e obrigatórias para a 
garantia dos direitos do acusado, seguindo o rito legalmente estabelecido ao processo (MEIRELLES; BURLE FILHO; BURLE, 2016, p. 832).

Assim, uma vez constado o agente público em uma transgressão disciplinar, a autoridade competente tornará público uma portaria descrevendo os atos ou fatos a apurar que apontem as infrações para que, posteriormente, recebam as sanções devidas. Nessa portaria já será designada a comissão processante, dando início, deste modo, ao procedimento administrativo (MEIRELLES; BURLE FILHO; BURLE, 2016, p. 831-832).

Após a publicação da portaria poderá existir casos em que ocorra a descoberta de novos fatos conexos ao principal, podendo assim, serem averiguados outros agentes ou outras condutas, desde que não embaracem o devido processo legal ou o direito a defesa. Caso algum desses quesitos seja prejudicado, a comissão deverá informar à autoridade competente para a denominação de uma nova comissão para o novo fato (MARINELA, 2018, p. 1.160).

Uma vez iniciado o processo administrativo os atos e fatos que vão ser apurados deverão ser descritos de forma motivada, ou seja, para que a legalidade, o contraditório e a ampla defesa possam ser analisados, deverá estar explícito a causa e os elementos que motivaram a lavratura do ato administrativo propriamente dito (SPITZCOVSKY, 2019, p. 720).

Meirelles, Burle Filho e Burle (2016, p. 110-111) complementam que o fato deverá ser motivado para que também a moralidade e a finalidade sejam aferidas e, ainda, referenciam que na motivação esteja explícito o embasamento legal. Fatores esses que implicam na eficácia do ato.

A partir do libelo acusatório a comissão deverá facultar ao acusado, ou ao seu advogado, a apreciação dos autos na seção, para que possa ser apresentada a defesa e, caso necessário, as indicações de testemunhas e provas de acordo com o prazo regulamentar (MEIRELLES; BURLE FILHO; BURLE, 2016, p. 832).

As provas destinadas a esclarecer os fatos serão produzidas na fase de instrução. Serão consideradas provas pertinentes os depoimentos da parte, testemunhas, perícias, análises ou exames pessoais assim como a ajuntada de documentos. Função essa que cabe à autoridade ou a comissão processante, ou, a pedido do acusado. Possui o objetivo de "averiguar e comprovar" os dados necessários para o julgamento (MELLO, 2010, p. 518). 
A terceira fase é a defesa que é uma garantia constitucional de qualquer indivíduo em litígio e compreende a notícia da acusação, acesso aos autos, oportunidade de defesa prévia e a produção de provas, como a indagação e reperguntas de testemunhas, sendo garantido a observância do devido processo legal (MEIRELLES; BURLE FILHO; BURLE, 2016, p. 826).

É após as oitivas das testemunhas que a Comissão Processante irá fazer o interrogatório do inquirido. E, caso haja mais de um acusado, serão ouvidos em separado e se houver discordância nos seus depoimentos, a Comissão promoverá a acareação deles (MARINELA, 2018, p. 1.162).

Conforme a súmula $\mathrm{n}^{\circ} 14$ do STF, também é garantido ao defensor do acusado o acesso aos objetos de provas já constados nos autos da investigação realizados por aquele que tem prerrogativas de polícia judiciária, o que faz jus ao direito de defesa.

Segundo Marinela (2018, p. 1.163), será considerado revel o acusado que não apresentar sua defesa dentro do prazo estabelecido em lei. A revelia será declarada em termo fixado nos autos e a comissão comunicará a autoridade instauradora do processo que indicará um servidor como defensor dativo. Esse defensor deverá ser efetivo, superior hierárquico ou de mesmo nível do acusado, com escolaridade superior ou igual.

A quarta fase, última tarefa da Comissão Processante, será o relatório com a síntese de todo o processo e seus procedimentos, que fará embasamento sobre a análise do caso (ARAGÃO, 2013, p. 1221). Assim, irá relatar se houve ou não transgressão disciplinar e, caso haja, com a sanção que entender cabível. Vale ressaltar que não é a comissão que vai inocentar ou impor a sanção ao agente público, pois vai dar o seu parecer e submeter seu relatório à apreciação da autoridade competente, assim de acordo com a Lei no: 8.112/90, artigos 165 e 166 .

Nesse ínterim, mostra-se a importância do relatório da comissão, em que citase a Lei . $^{\circ} 8.112$ de 1990, que busca limitar a discordância da autoridade apenas em conclusões da Comissão que estejam em contrário às provas dos autos, nos artigos 167 e 168.

Siqueira (2017, p. 02) afirma que todas essas garantias de direitos fazem parte de um Estado Democrático. Pois é a legalidade que protege a cidadania dos indivíduos, garantindo seus direitos de modo claro e objetivo. Porém, o singelo 
llegitimidade da comissão processante disciplinar frente às garantias constitucionais da ampla defesa e do contraditório

segmento das leis não basta para a obtenção da norma legítima. Os aspectos democráticos e suas garantias são pressupostos para a legitimidade da norma.

\section{A ILEGITIMIDADE DA COMISSÃO PROCESSANTE FRENTE ÀS GARANTIAS CONSTITUCIONAIS AOS LITIGANTES}

Engana-se em pensar que a Administração Pública é algo recente, pois ela sempre existiu. $O$ quê não havia era uma disciplina jurídica. Mesmo nos primórdios de povoados havia uma administração pública: era livre e soberana, e podia fazer tudo que the agradasse, sem a contestação de seus súditos (ARAGÃO, 2013, p. 53).

Hodiernamente, como já mencionado, o processo administrativo deve observar os princípios da ampla defesa e do contraditório (BRASIL, 1988), porque possui uma relação jurídica processual e um procedimento processual (ESPINOSA; SOARES, 2013, p. 11); compreendendo assim, através desses princípios, o devido processo legal (ROSSETTO, 2010, p. 06).

O devido processo legal é o princípio gerador de todos os demais princípios processuais. Possui sua parte material que são os conteúdos das regras processuais, devendo ser justas, racionais e razoáveis. E a formal que compreende as formalidades contidas na lei para a garantia processual do contraditório e da ampla defesa (BACELLAR FILHO, 2013, pp. 229, 232).

Princípios são teorias basilares que se justapõem a todo o ordenamento jurídico, são os meios pelos quais ocorre a conexão de toda lei e norma que será utilizada para a sentença. Os princípios, a analogia e a equidade foram invocadas pelo legislador para serem caminhos para intepretação das leis, pois não há como o legislador prever todas as hipóteses da vida real (ARAÚJJ, 2018, p. 71).

São os princípios constitucionais que orientam a interpretação do Direito Administrativo, não podendo ocorrer incoerência entre as normas e os princípios, quais sejam: legalidade; moralidade; impessoalidade; publicidade; eficiência; razoabilidade e proporcionalidade; segurança jurídica; motivação; interesse público; ampla defesa e o contraditório (MEIRELLES; BURLE FILHO; BURLE, 2016, p. 52).

Desses princípios, os cinco primeiros estão explicitamente elencados no artigo 37 da Constituição Federal, como princípios da Administração pública, direita e indireta (BRASIL, 1988). 
Todos esses princípios citados anteriormente estão, ainda, listados no artigo $2^{\circ}$ da Lei que regula o processo administrativo no âmbito federal (Lei n. ${ }^{\circ}$ 9.784/99), gerando a obrigação da observância desses princípios pela Administração Pública nos Processos Administrativos. Há, também, no inciso IV do parágrafo único desse artigo, a imposição de que o aplicador da Lei a interprete de acordo com os "padrões éticos de probidade, decoro e boa-fé". No mesmo parágrafo é disposto que o resultado obedeça à "adequação entre meios e fins", não impondo em "obrigações, restrições e sanções em medida superior àquelas estritamente necessárias ao atendimento do interesse público" (BRASIL, 1999)

Vale notar que, de acordo com a Lei n. ${ }^{\circ} 8.429$ de 1992, em seu artigo 11, é considerado "ato de improbidade administrativa, que atenta contra os princípios da Administração Pública, qualquer ação ou omissão que viole os deveres de honestidade, imparcialidade, legalidade e lealdade às instituições", destaca-se a parte das condutas que podem ser comissivas ou omissivas.

Essas premissas são tidas como espécies de garantias, pois, nas palavras de Ferreira Filho (2015, p. 97), não há como afirmar direitos sem o estabelecimento de garantias. Garantias são a proteção dos direitos tutelados pelo ordenamento jurídico, derivadas do próprio sistema constitucional. São as formas e ferramentas para se alcançar os direitos.

Nem todas as garantias estão explicitas em texto de lei, como nem todos os princípios citados anteriormente estão no cabeçalho do artigo 37 da Constituição Federal, assim como outro princípio do Direito Administrativo que está no artigo 70 da CF que é o da economicidade, é um exemplo. Os princípios implícitos, como o da indisponibilidade do interesse público e o da finalidade, sobrevêm da gradual formação da doutrina e da jurisprudência, assim como são decorrentes do Estado Democrático de Direito (ARAGÃO, 2013, p. 150).

Ainda, há o fato do Direito Administrativo sancionador se aproximar do Direito Penal, o qual busca por uma punição para as condutas ilegais. Desse modo, as sanções ao agente público ou ao terceiro, devem ser interpretadas conforme os princípios pertinentes aos direitos fundamentais da pessoa humana (OSÓRIO, 2005, p. 135-136). 
A dignidade da pessoa humana é um fundamento da República Federativa do Brasil, e está contido no inciso III do artigo $1^{\circ}$ da CF de 1988, no primeiro título dos princípios fundamentais.

Conforme Meirelles, Burle Filho e Burle (2016, p. 92), todos esses quesitos são padrões da Administração e deverão regular qualquer ato ou atividade da Administração Pública ou daquele que exerce o poder público. São, portanto, alicerces da atividade Administrativa, ou, nas palavras dos autores: "sustentáculos da atividade pública".

Diante dos princípios citados, nota-se que são várias as garantias e padrões administrativos que compõem o devido processo legal e, esse, por sua vez, garante a ampla defesa e o contraditório processual.

Não há de se falar em ampla defesa, sem se falar no princípio do contraditório: são princípios correlatos. Não é aceitável falar em ampla defesa sem se pressupor o contraditório. Assim como o devido processo legal é abrangente e compreende o princípio da ampla defesa (ROSSETTO, 2010, p. 07).

O devido processo legal é um "superprincípio" que guia todo o ordenamento jurídico, e foi a Constituição de 1988 que o trouxe para o Processo Administrativo. Ele implica no "fazer processo conforme a lei", referenciando ao princípio da legalidade; refere-se na maneira pela qual os procedimentos deverão ser realizados; garante que as relações com o Estado sejam igualitárias; remete a certeza que as decisões dos processos não vão ser arbitrárias e reafirma a legitimidade perante a pessoa (MARINELA, 2018, p. 1.135).

Diante disso, entende-se que a administração pública não poderá inferir nenhuma sentença sobre terceiro meramente diante daquilo que achar conveniente. Torna-se um "dever jurídico" a observância às normas, principalmente à Constituição Federal, no que tange ao princípio do contraditório e da ampla defesa (ROSSETTO, 2010, p. 21).

A ampla defesa e o contraditório são consequência do devido processo legal e, juntos, garantem: "o devido processo regular, participativo, legitimador da imperatividade de atos estatais, necessariamente impessoais, livres de perseguições, de favoritismos e pautados sempre pelo interesse público" (ROSSETTO, 2010, p. 06). 
Torna-se preciso então o entendimento em dizer que a ampla defesa é o direito do sindicante em saber por qual motivo está sendo indiciado, a ter acesso aos documentos do processo e, assim, a fazer a sua defesa prévia. Tem o direito de indicar e de produzir provas que achar conveniente à sustentação de sua defesa, como também a de possuir um advogado, assim podendo acompanhar as oitivas das partes e, se quiser, a fazer perguntas; oferecendo uma defesa final e, caso entenda, de poder recorrer (HERNANDEZ, 2000, p. 05).

Por sua vez, o contraditório é essencial para a consolidação da relação jurídica processual. Possui dois alicerces: o primeiro é a lógica da condição bilateral e o segundo é a política, que infere na condição para que ninguém seja processado e julgado sem ter conhecimento do processo e sem ser ouvido (MARINELA, 2018, p. 1.136).

Ainda, Rossetto (2010, p. 21) lembra que os procedimentos derivados da administração pública deixam de ser legítimos ao passo de que se deixa de dispor às partes interessadas a garantia de contestar a decisão da administração, assim como a de produzir provas contrárias, o que contrapõe o devido processo legal.

Ora, o ato administrativo deve se pautar na legalidade, assim como a moralidade necessita integrar todos os atos do Direito Administrativo. Desse modo, conforme acórdão do TJSP (SÃO PAULO, 2013, RDA 89/134): "[...] por legalidade ou legitimidade se entende não só a conformação do ato com a lei, como também com a moral administrativa e com o interesse coletivo".

Corroborando, o STF na ADI 2.661-5 (BRASIL, 2002), entende que 0 ato administrativo deverá ser anulado quando violar a moral administrativa, uma vez que ofenderá os princípios da confiança e da boa-fé.

Em continuidade, Meirelles, Burle Filho e Burle (2016, p. 95-96) declaram que a moralidade administrativa é necessária para que as ações do administrador público sejam consideradas válidas. Desse modo, será ilegítima toda a atividade pública que não estiver embasada na legalidade, assim como no amoldamento aos demais princípios.

Portanto, será considera ilegítima a ação da Comissão processante quando não estiver embasada nas leis. Como será também ilegítima a ação da Comissão que não orientar suas condutas sob à luz dos princípios. Ato ilegítimo será um ato inválido. 
Ato inválido é aquele ato que ofende os interesses públicos, é um ato ilegal e, por conseguinte, um ato nulo (GASPARINI, 2006, p. 113).

Ato nulo é aquele ato que não permite correção - muito menos correção com efeitos retroativos (convalidação) -, pois tem sua base na ilegalidade e, portanto, será um ato do qual não originará direitos, desse modo, terá efeitos retroativos, efeitos ex tunc (NOHARA; MARRARA, 2009, p. 341-343).

Por fim, o ato nulo implica na sua anulação (ou invalidação), que é o "desfazimento do ato". A anulação é uma modalidade do desfazimento volitivo que por sua vez é uma maneira pela qual o ato administrativo cessa seus efeitos, ou seja, a anulação implica na extinção do ato administrativo (CARVALHO FILHO, 2013, p. 263).

Logo, conhecendo-se os princípios citados e a base do processo administrativo, saber-se-á quais condutas podem ou não tornar ilegítimo o trabalho da Comissão Processante.

Destarte, além dos princípios da ampla defesa e do contraditório esclarecidos anteriormente, tem-se os explícitos no cabeçalho do artigo 37 da CF: legalidade; moralidade; impessoalidade; publicidade e eficiência.

Por legalidade impõe-se que o funcionário público não pode ter liberdade nem desejo pessoal. Aquele que trabalha pela administração púbica só lhe é permitido fazer o que está contido na lei. Do mesmo feito, não poderá ser descumprida por vontade ou acordo daqueles que a aplicam, é um dever, uma obrigação visando o bem comum que é o seu destinatário: a coletividade (NOHARA, 2018, p. 67-68).

A moralidade implica em que $\mathrm{o}$ ato administrativo deve obedecer à lei assim como a disciplina da própria instituição. Porque aquilo que é desonesto ou imoral pode também ser legal. Assim, a moralidade administrativa é a premissa da validade de toda conduta do agente administrativo (ALEXANDRE; DEUS, 2017, p. 162-163).

Encontra-se referência no âmbito infraconstitucional, na Lei n. ${ }^{\circ} 1.171$ de 1994 sobre o Código de Ética Profissional do servidor público civil federal, referente a moralidade administrativa, em que o servidor nunca poderá ignorar a ética em sua conduta, conforme o inciso "I" do anexo: "Assim, não terá de decidir somente entre o legal e o ilegal, o justo e o injusto, o conveniente e o inconveniente, o oportuno e o inoportuno, mas principalmente entre o honesto e o desonesto", sem ignorar os 
princípios da administração pública, contidos no caput do artigo 37 da Constituição Federal.

Do mesmo feito, a impessoalidade é paralela aos princípios da moralidade e da finalidade. A impessoalidade é fazer o quê tem que ser feito para aqueles que devem receber a ação ou omissão, jamais deverá o funcionário público fazer ou deixar de fazer algo de acordo com a sua vontade ou favorecimento. Impõe ao administrador que só pratique o ato administrativo para o seu fim legal. Pois os atos da administração pública devem ser atribuídos ao Estado, não a pessoa física que o praticou (ARAGÃO, 2013, p. 171).

O quê o princípio da impessoalidade ou da finalidade proíbe é a realização de um ato administrativo sem o mérito coletivo ou sem o interesse da Administração Pública, com o único objetivo de satisfazer interesses particulares, como favorecer ou prejudicar alguém (NOHARA, 2018, p. 72-74).

Meirelles, Burle Filho e Burle (2016, p. 98) afirmam que a pessoalidade é a atitude do funcionário público que configura em uma das modalidades mais comuns do desvio de poder.

O desvio de poder é quando o agente, mesmo dentro da sua discricionariedade, exerce sua função com interesses distintos do interesse público, divergindo dos interesses elencados na lei, gerando ainda a nulidade do ato administrativo (MELLO, 1988, p. 06-07).

É considerado uma "violação ideológica da lei", por meios imorais, revestido por um ato administrativo aparentemente legal (MEIRELLES; BURLE FILHO; BURLE, 2016, p. 123).

O desvio de poder é difícil de ser comprovado, pois o agente, já agindo com dolo, preenche os quesitos e exigências formais estabelecido em lei para o seu ato (ZYMLER, 2005, p. 121).

Porém, há alguns pressupostos que podem denunciar o desvio de poder, que de forma resumida, de acordo com Cretella Júnior (1976, p. 79-97), são: a contradição do ato com atos posteriores; contradição do ato com atos anteriores; uma motivação excessiva do ato; motivação contraditória do ato; motivação insuficiente; a falta de lógica manifesta; desigualdade de tratamentos e derrogação de norma interna. 
Em continuidade, o princípio da publicidade serve para o controle da juridicidade dos atos administrativos, abrindo a possibilidade deles serem contestados perante sua legalidade, legitimidade e da moralidade das ações do Poder Público; é a transparências dos atos administrativos. É um direito fundamental do administrado, uma vez que é através da disponibilidade dos fatos que os demais tomam ciência dele (MOREIRA NETO, 2014, p. 152).

A eficiência é a racionalização do órgão público, é otimizar o desempenho e resultados na prestação do serviço pelo agente visando a economia (DIAS; BIANCHINI; GOMES, 2012, p. 45).

Os demais princípios que orientam o devido processo legal são: da motivação, da razoabilidade e da proporcionalidade, da segurança jurídica, da celeridade e do interesse público (MOREIRA NETO, 2014, p. 251).

Todo ato administrativo deve ser motivado. Assim preconiza o princípio da motivação: não importando se vinculados ou discricionários, todo ato administrativo que implique em uma restrição ou afetem direitos tutelados ou na utilização de bens ou serviços públicos devem ser motivados. Essa motivação não pode ser meramente formalizada, deve ser suficiente; a qual deve constar os motivos que levaram para tal decisão, as circunstâncias, o embasamento legal e os meios que legitimam a ação (ARAGÃO, 2013, p. 184-185).

Essa motivação ainda deve ser transparente - princípio da publicidade - e consolidada para que possa ser contestada perante seu conteúdo. Fato esse que se relaciona com o Estado Democrático de Direito e com o devido processo legal e a ampla defesa, pois não há como embargar sem conhecer a causa do ato administrativo (MOREIRA NETO, 2014, p. 101).

Por sua vez, o princípio da razoabilidade é concomitante com o da proporcionalidade. A razoabilidade é a moldação do ato administrativo entre o meio legal e o meio utilizado pelo administrador. E o princípio da proporcionalidade está inserido no princípio da razoabilidade: realça a ação do administrador, devendo ser proporcional à dimensão da lesão, do dano ou do perigo causado pelo seu gerador. A não observância desses princípios também acarreta no ensejo ao abuso de poder (ZYMLER, 2005, p. 65).

Já o princípio da Segurança Jurídica impõe limites da autotutela pela Administração Pública, almejando a estabilidade das relações jurídicas, de modo 
que a revisão de seus atos por parte da administração não seja algo perpétuo (DIAS; BIANCHINI; GOMES, 2012, p. 49).

Sendo assim, a administração pública tem o limite de cinco (05) anos a partir da data que foi praticado o ato administrativo para anulá-los, uma vez sendo favoráveis ao destinatário, exceto quando verificada e comprovada a má-fé, conforme artigo 54 da Lei n. ${ }^{\circ} 9.784 / 99$.

Um exemplo de segurança jurídica está no artigo 27 da Lei n. ${ }^{\circ} 9.868 / 99$, que autoriza a implementação do efeito ex nunc na declaração de inconstitucionalidade de lei ou ato normativo quando essa declaração restringir direitos, ofender o princípio da segurança jurídica ou prejudicar relevante interesse social.

Ao passo que o princípio da celeridade impõe à Administração Pública que atue no processo administrativo com agilidade, com duração "razoável", e assegure a "celeridade de sua tramitação", conforme o artigo $5^{\circ}$, LXXVIII da CF.

O princípio da indisponibilidade do interesse público refere-se aos valores, pois todo interesse reflete um valor. Nas relações com a administração pública quem vai determinar o valor de cada interesse é a lei. Cabe à lei identificar e determinar um interesse, defini-lo e relacioná-lo com a coletividade e, priorizar, caso necessário, a forma de atendimento, mesmo com um sacrifício parcial ou total de ouros interesses. Desse modo, é papel da norma divulgar um interesse público específico e remeter ao Estado o "encargo finalístico de satisfazê-lo, definindo, em consequência, competências, condições de proteção e os direitos e deveres jurídicos correlatos" (MOREIRA NETO, 2014, p. 160).

São esses princípios que vão garantir o devido processo legal, resguardando aos inquiridos um procedimento imparcial e justo (ROSSETTO, 2010, p. 06-07) e, assim, mantendo a igualdade das pessoas em um Estado Democrático de Direito, obtendo as garantias do contraditório e da ampla defesa (HERNANDEZ, 2000, p. 04); logo, conforme Rossetto (2010, p. 06), trajando assim um processo sem perseguições por questões pessoais ou favorecimentos por amizades ou interesses, sempre pautado no interesse coletivo. 


\section{CONSIDERAÇÕES FINAIS}

O Processo Administrativo Disciplinar é uma ferramenta essencial para a Administração, assim como para terceiros, gerando e interferindo em direitos tutelados. Por esse motivo, busca-se uma transparência e garantias para esse ato, criando ainda a possibilidade de avaliação do Judiciário. Cabe, as partes, tanto os responsáveis pela garantia, como os acusados, a ideal compreensão da situação, visando sempre, a busca pela justiça mediante o devido processo legal, essencial em um Estado Democrático de Direito.

A banalização da aplicação de um processo administrativo disciplinar causa ojeriza ao administrado, ainda mais quando se percebe que foi oriundo do superego do administrador. Caberá ao indiciado a valoração dos motivos justificantes da abertura de um PAD, questionando-se se aquela falta administrativa merece o ensejo da instauração, se foi prejudicial para a Administração, se criou lesão ao serviço público ou qual o interesse público afetado. Sempre relacionando o caso aos princípios constitucionais.

Ora, com o conhecimento que o PAD é um ato administrativo, no mínimo, deverá o indiciado questionar a sua motivação, avaliando qual motivo foi usado para justificar sua abertura com o embasamento legal pertinente, procurando afastar sempre a impessoalidade.

São esses conhecimentos que levam aos interessados a aptidão de questionar com sabedoria e argumentos sobre a competência da Comissão, pois, poderá, o indiciado, encontrar situações em que os integrantes dela podem não ter o conhecimento básico de um processo administrativo, pois não há um cargo definido para essa função, havendo uma mera designação para o seu desempenho, sem esses funcionários conhecerem o mínimo de Direito.

Não obstante, uma Comissão Sindicante formada por agentes que possuem certa afinidade entre a autoridade delegante acaba divergindo-se do objetivo legal e podendo criar circunstâncias oriundas de interesses pessoais ao longo da inquirição, de acordo com a vontade do administrador; em que, por exemplo, perguntas tendenciosas realizadas às testemunhas. 
Todos esses conhecimentos convergem para a parte principal do trabalho, nas condições e circunstâncias que interferem na legitimidade da comissão, essenciais para a avaliação racional e legal ao caso em concreto.

A legitimidade, normalmente, é compreendida apenas com a relação de questões legais, com os atos descritos em lei. Sabe-se, pela pesquisa deste trabalho, que o ato legítimo também é relacionado com ações e atitudes morais, de acordo com os princípios constitucionais. Além disso, um ato ilegítimo é um ato nulo e causa a extinção do ato, perdendo assim seus efeitos jurídicos.

$O$ conceito de legitimidade se torna mais amplo ao se avaliar perante a Comissão as garantias da ampla defesa e do contraditório, pois é função desse grupo a garantia desses princípios.

Ao se julgar esses princípios, percebe-se que são derivados de um processo justo, imparcial, condizente com o princípio do devido processo legal. Pois, quando não há um processo baseando-se na legalidade, na moralidade, no justo e na impessoalidade, não há uma ampla defesa em sua plenitude, não há um contraditório imparcial. Não há, portanto, um devido processo legal, com condutas que não interfiram nos meios em que o indiciado poderá se valer para a devida defesa.

Nesse panorama, afirma-se a importância do princípio do devido processo legal, que é composto por vários outros princípios que o circundam. Ao não se observar algum desses princípios o devido processo legal é comprometido e, assim, interferindo na devida satisfação da ampla defesa e do contraditório.

A ilegitimidade da Comissão Sindicante está relacionada intrinsicamente com todos esses princípios. Situações que à primeira vista não parecem interferir na validade do ato devem ser observadas. Destaca-se a moralidade, como exemplo, dos integrantes da Comissão, uma vez que atitudes dos funcionários podem se revestir de legalidade, mas podem ser imorais ou desonestas.

O conhecimento de seus direitos e das condições que garantem a legitimidade da comissão se faz necessário uma vez que há grande dificuldade em se provar o desvio de poder de um ato administrativo quando o agente que 0 praticou já o realizou com má-fé. $O$ ato, aparentemente legal, será conduzido de uma forma para parecer válido, possuindo uma falsa legalidade, exposto em um cenário criado para justificar e mascarar tal situação, precedido de formalidades e 
etapas estabelecidas em lei. Devendo o indiciado, munido de conhecimento, revisar o ato desde sua origem, atentando-se para a sua verdadeira motivação, observando sua legitimidade, justificativa e motivação.

Diante do exposto, nota-se a necessidade da discussão do tema, pois a Comissão Processante deve garantir a ampla defesa e o contraditório de uma forma imparcial e justa, sem favoritismo oriundo de bajulações ou perseguições.

Portanto, é indiscutível o valor do ato administrativo pela influência desse tanto na Administração quanto nos direitos tutelados ao indivíduo. Assim como da necessidade de que a Comissão Processante tenha ciência da sua importância no litigio sancionador e dos preceitos que devem observar, diminuindo ou anulando as possíveis injustiças no âmbito administrativo. E, do mesmo modo, que os indiciados conheçam seus direitos e, principalmente, os princípios que circundam a legitimidade da Administração no Processo Administrativo Disciplinar, inibindo uma possível má-fé incutida no ato administrativo de um procedimento disciplinar.

Conclui-se que a legitimidade da Comissão não depende tão somente da observância das regras estabelecidas em lei, mas também com a interpretação e aplicação da norma com base nos princípios constitucionais, assim como a compreensão da matéria tanto pelos administradores quanto pelos indiciados, para que a ampla defesa e o contraditório sejam garantidos

\section{REFERÊNCIAS}

ALEXANDRE, Ricardo; DEUS, João de. Direito administrativo. 3.ed. São Paulo: Método, 2017.

ALMEIDA, Fabrício Bolzan de. Manual de direito administrativo. 3.ed. São Paulo: Saraiva, 2019.

ARAGÃO, Alexandre Santos. Curso de direito administrativo. 2.ed. Rio de Janeiro: Forense, 2013.

ARAÚJJ, Edmir Netto de. Curso de direito administrativo. 8.ed. São Paulo: Saraiva, 2018.

BACELLAR FILHO, Romeu Felipe. Processo administrativo disciplinar. 4.ed. São Paulo: Saraiva, 2013. 
BRASIL. Código de ética Profissional do servidor público civil do poder executivo Federal: decreto $n^{\circ} 1.171$ de 22/06/1994. Brasília, 1994.

BRASIL. Constituição da Republica Federativa do Brasil de 1988. Brasília: Assembleia Constituinte, 1988.

BRASIL. Dispõe sobre as sanções aplicáveis aos agentes públicos nos casos de enriquecimento ilícito no exercício de mandato, cargo, emprego ou função na administração pública direta, indireta ou fundacional e dá outras providências: lei nº 8.429 de 2/06/1992. Brasília, 1992.

BRASIL. Dispõe sobre o processo e julgamento da ação direta de inconstitucionalidade e da ação declaratória de constitucionalidade perante o Supremo Tribunal Federal: lei nº 9.868 de 10/11/1999. Brasília, 1999.

BRASIL. Dispõe sobre o regime jurídico dos servidores públicos civis da União, das autarquias e das fundações públicas federais: lei $n^{\circ} 8.112$, de 11/12/1990. Brasília: Senado Federal, 1990.

BRASIL. Regula o processo administrativo no âmbito da Administração Pública federal: lei nº 9.784 de 29/01/1999. Brasília: Senado Federal, 1999.

BRASIL. STF (Supremo Tribunal Federal). ADI 2.661-5. Relator Ministro Celso de Mello, junho de 2002.

BRASIL. STF (Supremo Tribunal Federal). Súmula $n^{\circ}$ 05. In: RE 434.059. Relator: Gilmar Mendes, J 07 de maio de 2008.

BRASIL. STF (Supremo Tribunal Federal). Súmula n 14. In: HC 88.190. Relator: Cézar Peluso, J 06 de outubro de 2006.

CAMPOS, Ana Cláudia. Direito administrativo facilitado. São Paulo: Método, 2019.

CARVALHO FILHO, José dos Santos. Processo administrativo federal. 5.ed. São Paulo: Atlas, 2013.

CARVALHO FILHO, José dos Santos. Manual de direito administrativo. 33.ed. São Paulo: Atlas, 2019.

COSTA, Elisson; BIANCHINI, Alice; GOMES, Luiz Flávio. Direito administrativo II: organização da administração, responsabilidade civil do Estado, agentes públicos e controle da administração. 32.ed. São Paulo: Saraiva, 2012.

COUTO, Reinaldo. Curso de direito Administrativo. 3.ed. São Paulo: Saraiva, 2019.

CRETELLA JÚNIOR, José. Sintoma denunciadores do "Desvio de Poder". Revista da Faculdade de Direito do Estado de São Paulo, São Paulo, v. 71, 1976. 
DI PIETRO, Maria Sylvia Zanella. Direito administrativo. 31.ed. Rio de Janeiro: Forense, 2018.

DIAS, Licínia Rossi Correia; BIANCHINI, Alice; GOMES, Luiz Flávio. Direito administrativo I: temas introdutórios e princípios da administração pública, atos administrativos, poderes da administração, improbidade administrativa. 31.ed. São Paulo: Saraiva, 2012.

ESPINOSA, Marcello; SOARES, Wilcinete dias. Poder disciplinar e processo administrativo. Revista científica semana acadêmica, Ceará, v.1, n. 040. 2013. Disponível em: <https://semanaacademica.org.br/artigo/poder-disciplinar-e-processoadministrativo>. Acesso em: 21 set. 2018.

FERREIRA FILHO, Manoel Gonçalves. Princípios fundamentais do direito constitucional. 4.ed. São Paulo: Saraiva, 2015.

GASPARINI, Diogenes. Direito administrativo. 11.ed. São Paulo: Saraiva, 2006.

HABERMAS, Jürgen. Direito e democracia: entre facticidade e validade. Tradução: Flávio Beno Siebeneichler. 2.ed. Rio de Janeiro: Tempo Brasileiro, 1997.

HERNANDEZ, Ary César. 0 contraditório e a ampla defesa no processo administrativo. 2000. Dissertação (Mestrado em Direito do Estado) - Universidade do Estado de São Paulo, São Paulo, 2000.

KNOPLOCK, Gustavo Mello. Manual de direito administrativo: teoria, doutrina e jurisprudência. 11.ed. Rio de Janeiro: Método, 2018.

MARINELA, Fernanda. Direito administrativo. 12.ed. São Paulo: Saraiva, 2018.

MEIRELLES, Hely Lopes; BURLE FILHO, José Emmanuel; BURLE, Carla Rosado. Direito Administrativo Brasileiro. 42.ed. São Paulo: Malheiros, 2016.

MELLO, Celso Antônio Bandeira de. Desvio de Poder. Revista de Direito Administrativo. Rio de Janeiro, v. 172, jan./mar. 1988.

MELLO, Celso Antônio Bandeira de. Curso de direito administrativo. 27.ed. São Paulo: Malheiros, 2010.

MOREIRA NETO, Diogo de Figueiredo. Curso de direito administrativo: parte introdutória, parte geral e parte especial. 16.ed. Rio de Janeiro: Forense. 2014.

NOHARA, Irene Patrícia. Direito administrativo. 8.ed. São Paulo: Atlas, 2018.

NOHARA, Irene Patrícia; MARRARA, Thiago. Processo Administrativo: Lei ${ }^{\circ}$ 9.784/99 comentada. São Paulo: Atlas, 2009.

OSÓRIO, Fábio Meina V. Direito administrativo sancionador. São Paulo: Revista dos Tribunais, 2005. 
ROCHA, Cármen Lúcia Antunes. Princípios constitucionais do processo administrativo no Direito brasileiro. Revista de informação Legislativa, Rio de Janeiro, v. 34, n. 136, p. 189-222, jul-set. 1997.

ROSSETTO, Giordano da Silva. A anulação do ato administrativo e o devido processo legal. Revista Zênite, Paraná, v. 9, n. 108, p. 1142-1157. 2010.

ROSSI, Licínia. Manual de direito administrativo. 4.ed. São Paulo: Saraiva, 2018.

SÃO PAULO. TJSP (Tribunal de Justiça do Estado de São Paulo). RDA 89/134. Relator Desembargador Cardoso Rolim, 2013.

SILVA, Jesué Graciliano da; MELLO, Rogério. Perguntas e respostas sobre processo administrativo disciplinar. Instituto Federal de Santa Catarina, 2018. Disponível em: <https://eticaegestao.ifsc.edu.br/formacao-de-gestores/perguntas-erespostas-sobre-processo-administrativo-disciplinar>

Acesso em: 21 set. 2018.

SIQUEIRA, Gustavo Silveira. Direito, democracia e legitimidade. Universidade Federal de Minas Gerais, 2017.

SPITZCOVSKY, Celso. Direito administrativo esquematizado. 2.ed. São Paulo: Sarava, 2019.

ZYMLER, Benjamin. Direito administrativo. Editora Fortium, 2005.

Artigo recebido em: 28/10/2019

Artigo aceito em: 04/05/2020

Artigo publicado em: 02/06/2020 